E3S Web of Conferences 1, 11007 (2013)

DOI: $10.1051 / \mathrm{e} 3$ sconf/20130111007

(c) Owned by the authors, published by EDP Sciences, 2013

\title{
Accumulation of heavy metals in the muscles of Zander from Novosibirsk water basin
}

\author{
I. S. Miller ${ }^{1}$, V. L. Petukhov ${ }^{1}$, O. S. Korotkevich ${ }^{1}$, G. N. Korotkova ${ }^{1}$ and I. S. Konovalov ${ }^{2}$ \\ ${ }^{1}$ Novosibirsk State Agrarian University, 160 Dobrolubov Str., Novosibirsk 630039, Russia, vpetukhov@ngs.ru \\ ${ }^{2}$ Novosibirsk State Technical University, 20 C. Marx Avenue, Novosibirsk 630092, Russia, iluhster@mail.ru
}

\begin{abstract}
The content of iron, zinc, copper, manganese, lead and cadmium has been studied in vastus muscle of the zander from Novosibirsk water basin upstream waters. The ranged row of the chemical elements levels was as follows: $\mathrm{Fe}>\mathrm{Zn}>\mathrm{Cu}>\mathrm{Mn}>\mathrm{Pb}>\mathrm{Cd}$. The concentration of all the elements, except for iron, did not exceed maximum permissible concentrations (MPC). The content of iron in zander muscles was 1.06 times higher than MPC. For the past 17 years, concentrations of heavy metals such as $\mathrm{Cd}, \mathrm{Fe}, \mathrm{Zn}, \mathrm{Mn}$ and $\mathrm{Pb}$ in zander muscles decreased several times as much. It was determined that correlations among chemical elements in zander muscles were different in value and direction.
\end{abstract}

Key words: zander, muscles, heavy metals, correlations

\section{Introduction}

For the past years, anthropogenic pollution of the environment with heavy metals has become one of the obvious threats to all living organisms including man. Most metals are natural environmental components involved in a great many enzymatic reactions in vital activity of organisms and their deficiency is sometimes as harmful as their excess $[1,2,3]$. When they are in excess, the problem is aggravated by the capacity of heavy metals to get accumulated and retain at all the levels of ecological pyramid, which can lead to distant effects as many metals are carcinogenic and mutagenic substances [1]. The negative effect of heavy metals interaction with intracellular systems is associated with the processes such as: replacing essential metals by toxic ones, bonding of some molecules needed for normal functioning of a cell, formation of toxic complexes, macromolecules depolymerization, breaches in the functioning of chromosome apparatus, etc., [4]. $\mathrm{Cu}, \mathrm{Cr}^{5+}$, $\mathrm{Cd}, \mathrm{Hg}$ (their $\mathrm{MPC}_{\mathrm{px}}$ in surface waters is $0.5-1.0 \mathrm{mg} / \mathrm{l}$ ) as well as $\mathrm{As}, \mathrm{Co}, \mathrm{Ni}, \mathrm{Pb}$ ( their $\mathrm{MPC}_{\mathrm{px}}$ is $10 \mathrm{mcg} / \mathrm{l}$ ) refer to the elements of high toxicity degree [5]. Cr, Mn, Fe, Co, $\mathrm{Ni}, \mathrm{Zn}, \mathrm{Se}, \mathrm{Ag}, \mathrm{Cd}, \mathrm{Hg}$, $\mathrm{Tl}$ and $\mathrm{Pb}$ are referred to super dangerous elements which half-excretion from both sea and freshwater fishes is over 10 days.

The information about the level and character of accumulated metals in fish organs and tissues can be used as one of the indicators pointing to the degree of water basin pollution by these elements, the one being applicable to estimating their migration in ecosystems [6]. The knowledge of composition and quantity of metals in the tissues (muscle, in the first place) of marketable fishes are of high practical value because of the necessity to determine their standard content in fish stuffs [7].

\section{Materials and Methods}

The examination was carried out on the basis of the laboratory of Siberian Institute of Livestock Breeding. The object to examine was the 3-4.4 year-old zander (Stizostedion lucioperca) that had been caught in Novosibirsk water basin downstream waters in the period from November to December, 2011. The total area of the basin is $1082 \mathrm{~km}^{2}$, mean depth is $8.3 \mathrm{~m}$, the largest depth being $25 \mathrm{~m}$. 20 samples were taken from muscle tissue to examine. The concentration of heavy metals was determined in air-dry substance with atomic absorption method.

The data obtained were processed biometrically with Microsoft Excel software.

\section{Results and Discussion}

The data of Table 1 about the content of heavy metals $(\mathrm{Cd}, \mathrm{Pb}, \mathrm{Fe}, \mathrm{Mn}, \mathrm{Cu}, \mathrm{Zn})$ in zander muscles can be used as the population mean values for zander muscle tissue.

Table 1. Heavy metals content in muscles, $\mathrm{mg} / \mathrm{kg}$

\begin{tabular}{|c|c|c|c|c|}
\hline $\begin{array}{c}\text { Metal } \\
\text { type }\end{array}$ & $\begin{array}{c}\text { ⿴囗十 } \\
\mathrm{ME}\end{array}$ & $\mathrm{S}$ & $\lim$ & $\begin{array}{c}\text { Ratio of } \\
\text { marginal } \\
\text { variants }\end{array}$ \\
\hline
\end{tabular}




\begin{tabular}{|c|c|c|c|c|}
\hline $\mathrm{Cd}$ & $\begin{array}{c}0.0083 \\
\pm 0.001\end{array}$ & 0.052 & $\begin{array}{c}0.0025- \\
0.0192\end{array}$ & $1: 7.7$ \\
\hline $\mathrm{Pb}$ & $\begin{array}{c}0.0769 \\
\pm 0.008\end{array}$ & 0.036 & $\begin{array}{c}0.0362- \\
0.1654\end{array}$ & $1: 4.6$ \\
\hline $\mathrm{Fe}$ & $\begin{array}{c}31.84 \pm \\
3.51\end{array}$ & 15.32 & $15-70$ & $1: 4.6$ \\
\hline $\mathrm{Mn}$ & $\begin{array}{c}2.026 \pm \\
0.439\end{array}$ & 1.87 & $0.4-7.1$ & $1: 17.8$ \\
\hline $\mathrm{Cu}$ & $\begin{array}{c}3.055 \pm \\
0.300\end{array}$ & 1.34 & $1.2-5.8$ & $1: 4.8$ \\
\hline $\mathrm{Zn}$ & $\begin{array}{c}19.23 \pm \\
\end{array}$ & 3.645 & $15-26.2$ & $1: 1.8$ \\
\hline
\end{tabular}

High individual variability is revealed for the concentration of heavy metals in muscles. The lowest phenotypic variability was characteristic for zinc content (C.V. $=15 \%)$.

$\mathrm{Pb}, \mathrm{Cd}, \mathrm{Cu}, \mathrm{Zn}$ and $\mathrm{Mn}$ concentrations varied within the limits of sanitary standards. However, for the content of $\mathrm{Fe}$, there was moderate exceeding MPC (maximum permissible concentration), 1.06 times as much. This seems to result from the negative impact of anthropogenic pollution on the water body ecosystem. Comparing the data obtained to those of P.A. Popov [7], who investigated zander in the Novosibirsk water basin in June, 1991; June, 1992; October 1994 and August 1998, and to the data obtained by us, it can be evident that the muscles of the zander caught by us in 2011 compared to the year 1991 contained lower concentrations of $\mathrm{Mn}, \mathrm{Fe}, \mathrm{Cu}, \mathrm{Zn}$ and $\mathrm{Pb}$, they were 3.3, $1.28,1.85,1.08$ and 20.7 times as little, respectively. In comparison with the year $1992, \mathrm{Fe}, \mathrm{Cu}, \mathrm{Pb}$ and $\mathrm{Cd}$ concentrations went down 1.36, 2.19, 33.3 and 50 times as little, respectively, but the concentrations of $\mathrm{Mn}$ and $\mathrm{Zn}$ went up 1.58 and 1.08 times as much. When we compared the year 1994 with the year 2011, the following was found out: $\mathrm{Fe}, \mathrm{Pb}, \mathrm{Cd}, \mathrm{Mn}$ and $\mathrm{Zn}$ concentrations were $15,48,15,1.15$ and 1.64 times as little, respectively. At the same time, $\mathrm{Cu}$ concentration increased 1.98 times as much, i.e., the concentrations of $\mathrm{Cd}, \mathrm{Pb}$ and $\mathrm{Fe}$ tended to decrease. Considerable variations in the muscle concentration of $\mathrm{Mn}, \mathrm{Cu}$ and $\mathrm{Zn}$ took place in 1991-2011. The increased concentration of any of the metals can occur with its relatively moderate content in a water body under dramatic or chronic changes of environmental conditions for the parameters such as: acidification, abnormally high temperatures, water body pollution with organic and other compounds, or weakened status of fishes suffering from diseases of infectious, parasitic and other etiologies. The decrease of the metals concentration in the muscle tissue of the Novosibirsk water basin zander can be ranged according to our data in the following order: $\mathrm{Fe}>\mathrm{Zn}>\mathrm{Cu}>\mathrm{Mn}>\mathrm{Pb}>\mathrm{Cd}$. For P.A. Popov's data of the year 1994, the ranged row was as follows: $\mathbf{F e}>\mathbf{Z n}>\mathbf{P b}>\mathbf{M n}>\mathbf{C u}>\mathbf{M n}>\mathbf{C d}$ [6], but in 1998, it was identical to our ranging: $\mathrm{Fe}>\mathrm{Zn}>\mathrm{Cu}>\mathrm{Mn}>\mathrm{Pb}>\mathrm{Cd}$. In the zander, we caught in 2011; iron, zinc and copper were dominating, which corresponds to the data on the level of heavy metals in sea fish muscles [8]. While the content of metals in muscles of the zander from Yugoslavian part of the Danube varied in the ranged order: $\mathrm{Zn}>\mathrm{Cu}>\mathrm{Pb}>\mathrm{Cd}>\mathrm{Fe}>\mathrm{Mn}[9]$, the zander of the upper $\mathrm{Ob}$ had the following range: $\mathrm{Fe}>\mathrm{Zn}>\mathrm{Mn}>\mathrm{Cu}>\mathrm{Pb}>\mathrm{Cd}$. This seems to result from the impact of an anthropogenic factor and, consequently, from different concentrations of heavy metals in the water of water bodies examined in different areas.

Distribution of heavy metals in the muscles of the fish species examined is characterized by heterogeneity, which depends on physicochemical properties of the elements and functional characteristics of muscles. Interrelations among chemical elements in zander muscle tissue are studied (Table 2).

Table 2. Correlation between heavy metal levels examined

\begin{tabular}{|c|c|c|c|}
\hline $\begin{array}{c}\text { Correlating } \\
\text { trait }\end{array}$ & $\mathrm{r}$ & $\begin{array}{c}\text { Correlating } \\
\text { trait }\end{array}$ & $\mathrm{r}$ \\
\hline $\mathrm{Cd}-\mathrm{Fe}$ & 0.408 & $\mathrm{Fe}-\mathrm{Cd}$ & 0.408 \\
\hline $\mathrm{Cd}-\mathrm{Mn}$ & 0.570 & $\mathrm{Fe}-\mathrm{Pb}$ & 0.550 \\
\hline $\mathrm{Cd}-\mathrm{Zn}$ & 0.467 & $\mathrm{Fe}-\mathrm{Mn}$ & 0.889 \\
\hline $\mathrm{Pb}-\mathrm{Fe}$ & 0.550 & $\mathrm{Zn}-\mathrm{Cu}$ & -0.350 \\
\hline $\mathrm{Mg}-\mathrm{Mn}$ & -0.429 & & \\
\hline
\end{tabular}

Cd level positively correlates to $\mathrm{Mn}(\mathrm{r}=0.570)$, it correlates less to $\mathrm{Zn}(\mathrm{r}=0.467)$ and $\mathrm{Fe} \quad(\mathrm{r}=0.408)$. Consequently, $\mathrm{Cd}$ facilitates the accumulation of some chemical elements.

The data about $\mathrm{Zn}$ influence on $\mathrm{Cd}$ distribution are often discrepant $[10,11]$. On the one hand, the ratio of cadmium and zinc is of antagonistic character. Meanwhile, a number of investigations mark that with the absence of zinc in a diet, no zinc-theonine, that is one of the major $\mathrm{Cd}$ receptors, synthesizes in liver and, consequently, $\mathrm{Cd}$ accumulation goes down in this organ. Besides, cadmium activates some zinc-independent enzymes in vitro: tryptophan, oxygenase, DALAdehydratase and carboxypeptidases.

Negative correlation is observed between manganese and magnesium $(r=-0.429)$. Both manganese and magnesium protect the organism from infections producing an influence upon the organism immune defense. Apparently, manganese deficiency causes the shortage of magnesium.

Iron level positively correlates to manganese $(\mathrm{r}=0.890)$, which is evidently associated with its being needed for erythrogenesis and hemoglobin production. To a less extent, iron correlates to zinc and cadmium, which may testify to the defensive response of the organism.

The level of zinc negatively correlates to copper. It is not rare when the deficiency of copper in the organism is of secondary character because zinc prevents its absorption. For all that, disorders in bone tissue (osteoporosis) arise; arteries elasticity and hemoglobin synthesis fail.

\section{Conclusion}

Population means are determined in the content of heavy metals in muscle tissue of the zander from Novosibirsk water basin. The concentrations of the metals such as 
$\mathrm{Mn}, \mathrm{Fe}, \mathrm{Zn}, \mathrm{Cd}$ and $\mathrm{Pb}$ tend to decrease in the zander of Novosibirsk water basin. Rows of the heavy metals are similar in the muscles of sea and fresh water bony fishes. $\mathrm{Pb}, \mathrm{Cd}, \mathrm{Cu}$ and $\mathrm{Zn}$, Mn concentrations were within the limits of sanitary standards. In Fe, MPC exceeding, 1.06 times as much, is observed. Cadmium level positively correlates to manganese, zinc and iron, but iron level positively correlates to manganese. Negative correlation is observed between manganese and magnesium, zinc and copper.

\section{References}

1. I.N., Andreichenko S.V, Golub I.A. Ichthyofauna of the Denube river as a bioindicator of ecosystem pollution with heavy metals // Burning issues of transport medicine. 2005. - №1. - P. 106.

2. Koropatnic J. Metallothionine and metal homeostasis / In cellular and molecular biology of metals. Edited by Zalups R., Koropatnic J. Taylor \& Francis Group, 2010. - p. 143-166.

3. Lall S.P., Milley. Trace mineral requirements of fish and crustaceans / In. Trace elements in animal production systems. Edited by Schlegel at al., 2008. - pp.
203-214.

4. Eihenberger E. Relation between need and toxicity of heavy metals in water ecosystems // Some issues of toxicity of metal ions. 1993. -P. 62.

5. Bespamyatov G.P., Krotov Yu. A. Maximum permissible concentrations of chemical elements in environment. L., 1985. -P 163.

6. Parks J., Curry C., Romani D. et al. Young northern pike yellow perch and crayfish as bioindicators in a mercury contaminated watercourse//Environ. Monit. and Assessment.1991. Vol.16. №1. P. 39-60.

7. Popov P.A. Estimation of ecological conditions of water bodies with ichthyoindication methods. Novosibirsk, 2002. - pp. 269.

8. Morozov N.P., Petukhov S.A. Microelements in marketable ichthyofauna of the world ocean. M., 1986. pp. 160 .

9. Evtushenko N.Yu., Sytnik Yu.M., Shapoval T.N. Heavy metals in the fishes of the mid-Denube // Water resources. 1993. V. 20, №5. -pp. 605-614.

10. Jacobs R., Jones A., Fry B., Fox M.// J.Nutr. 1978. - Vol.108.№6. - P. 901-910.

11. Nakamura K., Suzuki E., Sugiura I., Torat T. // Industr. Hlth. - 1979. - Vol. 17, №1. - P. 1-9. 